\title{
The influence of sub-lethal levels of zinc on smoltifying Atlantic salmon Salmo salar and on their subsequent susceptibility to infection with Lepeophtheirus salmonis
}

\author{
A. Ibrahim, B.M. MacKinnon \& M.D.B. Burt \\ Department of Biology, Bag Service \#45111, University of New Brunswick, Fredericton, N.B. E3B $6 E 1$ \\ Canada. Corresponding author: Dr. B.M. MacKinnon, e-mail: bmackinn@unb.ca
}

Keywords: Lepeophtheirus salmonis, Atlantic salmon, zinc toxícity

\begin{abstract}
Smoltifying Atlantic salmon were treated for 6 weeks in freshwater with 0,200 , and $400 \mathrm{ppb}$ zinc (as $\mathrm{Zn} \mathrm{SO}$ ). After 6 weeks salmon were transferred to a salt water seapen and exposed to infection with Lepeophtheirus salmonis for 14 weeks. Zine treatment resulted in some physiological changes consistent with increased stress, such as decreased leukocrit values, and increased plasma cortisol levels. Plasma glucose levels were significantly elevated in fish previously treated with zinc, but this was only evident after fish had been in a seapen, 14 weeks subsequent to treatment. Improved conversion of tetraiodothyronine to triiodothyronine, as well as no changes in interrenal cell nuclear diameters suggested that overall stress effects were low. Fish exposed to $200 \mathrm{ppb}$ and $400 \mathrm{ppb}$ zinc showed gill pathology. Infection intensity with $L_{\mathrm{x}}$ salmonis was significantly higher on salmon previously exposed to $400 \mathrm{ppb}$ zinc. This research suggests that for smoltifying Atlantic salmon, the No Observed Pathological Effect (NOPE) level for exposure for $\mathrm{ZNSO}_{4}$ may be around $150 \mathrm{ppb}$.
\end{abstract}

\section{Contents}

Introduction

Material and methods

Fish source and maintenance

Experimental design * 120

Sampling and analysis $\quad 120$

Results

Condition factor

Blood analysis

Histology

Zinc accumulation

Infection intensity

Discussion

Acknowlegdements

References

\section{Introduction}

Historically the Northwest Miramichi, in New Brunswick, Canada, had a large population of Atlantic salmon and was a world-famous salmon-fishing river. In more recent years, these stocks have declined dramatically. This decline may, in part, be correlated with the increase in mining and smelting operations on the river which have resulted in increased levels of heavy metals in the water. Elevated levels of heavy metals are toxic to aquatic organisms. High levels of zinc are toxic to salmonids (Skidmore, 1970) with Oncorhynchus, Salmo and Salvelinus genera varying in their susceptibility (Herbert and Wakeford, 1964). Atlantic salmon are the most sensitive of the species within these genera. Sprague et al. (1964) reported that Atlantic salmon die after 32 hours exposure to 600 ppb zinc. Toxic levels of zinc cause gill epithelia to uplift and thus fish die from asphyxia (Crandall and Goodnight, 1963; Lloyd, 1960; Skidmore, 1970; Skidmore and Tovell, 1972). Zinc also competitively inhibits branchial uptake of calcium $\left(\mathrm{Ca}^{2++}\right)$ which disrupts ionic and osmotic regulation and fish die from osmotic stress (Spry and Wood, 1985). Chronic sub-lethal levels of zinc can cause reproductive impairment in fish (Brungs, 1969; Eaton, 1973; Spehar, 1976; Sprague et al., 1964).

The presence of elevated zinc levels in spawning rivers may be particularly harmful to smoltifying " salmon, more so than to adult fish. Smoltification is a stressful process to salmon and circulating corticosteroid levels are elevated at this time (Schreck, 1982). This natural physiological stress 
may compound the stress caused by elevated zinc levels such that smolts may die at zinc levels lower than the lethal levels recorded for adult fish.

As far as we are aware, no studies have examined the longer-term effects of exposure of Atlantic salmon to sub-lethal levels of zinc while they are smoltifying in rivers that have elevated heavy metals. The objective of this particular study was to examine the effect of sub-lethal levels of zinc on smoltifying Atlantic salmon and to assess the susceptibility of these salmon to infection once they enter salt water using the salmon louse, Lepeophtheirus salmonis as the experimental infectious agent. To assess the effects of zinc, fish were analysed for condition factor, blood haemocrit, plasma cortisol, plasma glucose, tetraiodothyronine (T4), triiodothyronine (T3), head kidney cell nuclear diameter and gill morphology at the start of the trial and at the end of the zinc treatment. To assess the longer- term effect of zinc on salmon, the fish were tested for their susceptibility to infection with sea lice, $L$. salmonis, 14 weeks after the end of the zinc exposure period. Condition factor, plasma glucose levels, and interrenal cell nuclear diameter were also assessed at this time, as corroborating estimates of stress levels in the fish.

\section{Materials and methods}

\section{Fish source and maintenance}

Atlantic salmon 1+ smolts were purchased from the Atlantic Salmon Federation and held at the Huntsman Marine Science Centre, St. Andrews, N.B. Prior to the onset of the experiment, fish were acclimated for two weeks to their new environment. Fish were maintained in a flow-through system (flow rate $5 \mathrm{~L} / \mathrm{min}$ ) in fresh water at a stocking density of 50 fish $/ 2 \mathrm{~m}^{3}$ tank. Water $\mathrm{pH}$ was 6.6 and natural zinc levels were $0.012 \mathrm{ng} / \mathrm{L}$. Fish were fed to satiation daily with Moore-Clark pelleted dry feed.

\section{Experimental design}

The trials consisted of three groups of Atlantic salmon exposed to either no extra zinc (controls),
$200 \mathrm{ppb}$ zinc, or $400 \mathrm{ppb}$ zinc. Zinc sulphate predissolved in distilled water to a concentration of $17.6 \mathrm{~g} / \mathrm{L} \mathrm{ZnSO}{ }_{4}(17.6 \mathrm{ppt})$ or $8.8 \mathrm{~g} / \mathrm{L} \mathrm{ZnSO}_{4}(8.8$ ppt) was added to appropriate tanks by regular drops produced by peristaltic pumps. The final concentration of zinc in each tank was monitored regularly using the Dithiozone (diphenylthiocarbozone) analysis method (Sandell 1968). Each group had three replicates consisting of 50 fish in each of 3 $2 \mathrm{~m}^{3}$ tanks. Fish were exposed to zinc for 6 weeks from mid May to end June, 1996. Treatments then stopped and fish were anaesthetised with 2 phenoxy-ethanol and were fin clipped for identification by experimental group only (not by each tank). Fish were then acclimated to salt water for a further 2 weeks.

All fish were transported to a local fish farm and kept in a single $15 \mathrm{~m}^{3}$ seapen for 12 weeks, during which time they were naturally exposed to sea lice, emanating from nearby infected fish.

\section{Sampling and analysis}

At the beginning of the trials (week 0 ), after 6 weeks (week 6) of treatment and at the end of the experiment (week 20) all fish were anaesthetised and measured for fork length and weight. Condition factor was calculated using the equation

$$
\mathrm{CF}=\frac{\text { weight }(\mathrm{g}) \times 100}{\text { length }\left(\mathrm{cm}^{3}\right)}
$$

Blood samples

At weeks 0 and 6, five fish from each tank were netted and blood samples immediately drawn from the caudal vein using heparinized vacutainer tubes. At week 20, when all fish were in the common seapen cage, fish were netted and blood was collected from the first three fish from each experimental group as above.

Subsamples of fresh blood were immediately drawn into capillary tubes and the ends of tubes sealed for haematocrit analysis. Blood was then centrifuged at $3000 \mathrm{~g}$ for $5 \mathrm{~min}$ and the sera stored at $-70^{\circ} \mathrm{C}$ until analysed for cortisol, glucose, $\mathrm{T}_{3}$ and $\mathrm{T}_{4}$ : 
For haematocrit analysis, capillary tubes were centrifuged at $3000 \mathrm{~g}$ for 5 minutes and the relative volume of packed leucocytes and erythrocytes was assessed using the method of Snieszko (1960). Plasma cortisol, $T_{3}$ and $T_{4}$ were assayed using separate radio-immunoassay kits (Gamma coat 125I Clinical Assay, INCSTAR Corporation, Minnesota, USA). Plasma glucose levels were determined using a colorimetric glucose oxidase analysis kit (Sigma). Inter- and intra-assay variance was $<10 \%$.

\section{Tissue samples}

At weeks 0 and 6 , three fish from each tank were killed by a blow to the head and were immediately dissected to provide gill and head kidney tissue.

Head kidney tissue was fixed in Bouin's fluid, and later dehydrated and embedded in paraffin wax for sectioning at 7-10 $\mu \mathrm{m}$. Sections were stained in Harris-haematoxylin and eosin. The diameters of interrenal cell nuclei were measured for 20 randomly selected cells from three different areas of each head kidney sample using oil immersion, and their means calculated.

Gill tissue was fixed in Karnovsky's fixative (Karnovsky, 1965) pH 7.2, for 6 hours, rinsed in sodium cacodylate buffer, and post-fixed in $1 \%$ osmium tetroxide. Tissue was then dehydrated in acetone and embedded in Epon-Araldite. Sections $1 \mu \mathrm{m}$ thick were stained with $1 \%$ toluidine blue, and mounted with a coverslip. Sections from control fish were compared with those exposed to 200 and $400 \mathrm{ppb}$ Zinc for qualitative differences.

Quantitative differences were obtained by measuring percent area occupied by the gill epithelium and the area between secondary lamellae, using a wild M20 microscope coupled,with an Elmo Ccd TV camera and monitor screen with 42 point Mertz grid.

\section{Infection intensity}

At the end of 12 weeks in a single seapen (week 20 ), all fish were removed from the seapen and killed by a blow to the head. These were placed in individual plastic bags and frozen for future analysis of sea lice numbers on each fish. Fish were later thawed and the total number of attached larvae were counted on a subsample of $\mathbf{3 0}$ randomly selected fish. Mobile lice stages were not counted as some of these can be easily lost during capture particularly during rough, windy and cold conditions as were experienced during this study. The prevalence and mean intensity of infection were calculated for each experimental group of fish, according to the terms used by Margolis et al. (1982).

\section{Zinc levels in liver and gill tissue}

As confirmation that fish were physiologically exposed to three different levels of zinc, the zinc content of gill and liver tissue was assayed. At week 6 , gill and liver tissue were removed from each of three sacrificed fish per tank and frozen until analysed. Tissue samples were later accurately weighed, oven dried at $60^{\circ} \mathrm{C}$ for $72 \mathrm{hrs}$ and reweighed to determine moisture content. Samples were digested with high purity nitric acid and diluted to a standard volume for analysis of the trace element by inductively coupled plasma mass spectrometry, conducted by the Research and Productivity Council, Fredericton, N.B.

\section{Statističal analysis}

All data were transformed using either square root transformation or Arcsin transformation to stabilize the variance (Sokal and Rohlf, 1969; Zar, 1984). Data were then analysed using Tukey's comparison of means test. All results are expressed as mean $\pm \mathrm{SE}$ of raw data.

\section{Results}

\section{Condition factor}

Average condition factors ranged from $0.9 \pm 0.02$ $-1.1 \pm 0.04$ and were not significantly different for all groups of fish. Condition factors were not affected by the zinc treatment and did not change significantly when fish were held in salt water. 


\section{Blood analysis}

\section{Haematocrit}

Treatment with $200 \mathrm{ppb}$ zinc did not significantly affect the percentage of red or white blood cells in fish. Treatment with $400 \mathrm{ppb}$ zinc significantly increased the red cell volume and decreased the white cell volume, increasing the total packed cell volume in blood samples taken from fish at the end of zinc treatment at week 6 (Fig. 1a, b).

\section{Cortisol}

There was no significant difference between treatment groups prior to exposure to zinc. Salmon in all groups had significantly higher plasma cortisol levels after 6 weeks of treatment compared with levels at the start of the experiment. Fish exposed to $200 \mathrm{ppb}$ for 6 weeks generally showed elevated cortisol levels, however, these were not significantly different from controls. There were significantly higher levels of plasma cortisol in fish exposed to $400 \mathrm{ppb}$ zinc when compared to the controls. (Fig. 2).

$\mathrm{T}_{3}, \mathrm{~T}_{4}, \mathrm{~T}_{4} / \mathrm{T}_{3}$

Levels of $T_{3}, T_{4}$ and the ratio of $T_{4} / T_{3}$ were not significantly different at week 0 . Treatment with $400 \mathrm{ppb}$ zinc significantly increased plasma $T_{3}$ and decreased plasma $T_{4}$ levels in fish at week 6, compared with levels in fish receiving no zinc. Differences between fish receiving 200 and $400 \mathrm{ppb}$ were not significant. The ratio of $T_{4} / T_{3}$ was significantly lower in fish receiving both levels of zinc treatment when compared with controls, but the ratios were not significantly different between fish receiving 200 or 400 ppb zinc (Fig. 3a, b, c). Plasma $\mathrm{T}_{4}$ and the $\mathrm{T}_{4} / \mathrm{T}_{3}$ ratio were significantly higher at week 6 compared to week 0 , in all groups of fish. Plasma $\mathrm{T}_{3}$ was significantly higher at week 6 compared to week 0 in fish exposed to $400 \mathrm{ppb}$ zinc.

\section{Glucose}

Plasma glucose levels were not significantly different in fish having received 200 or $400 \mathrm{ppb}$ zinc

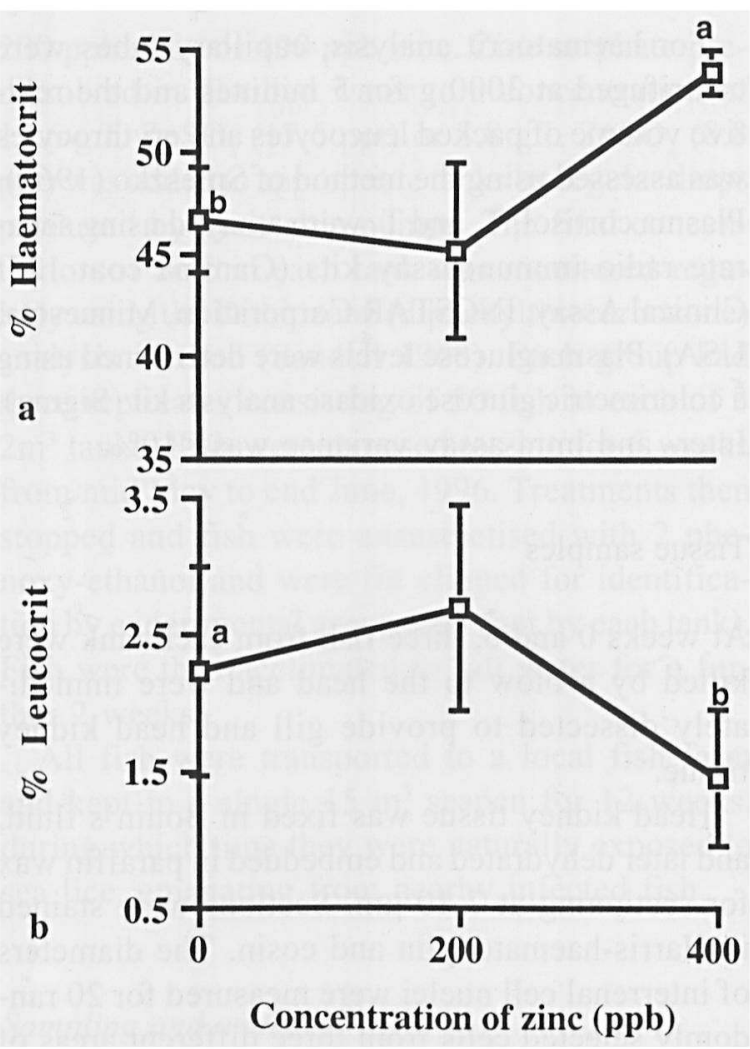

Fig. la,b. Average Haematocrit (a) and leucocrit (b) values \pm SE for Atlantic salmon after 6 weeks of treatment with either 200 or $400 \mathrm{ppb}$ zinc. Means with different letters are significantly different.

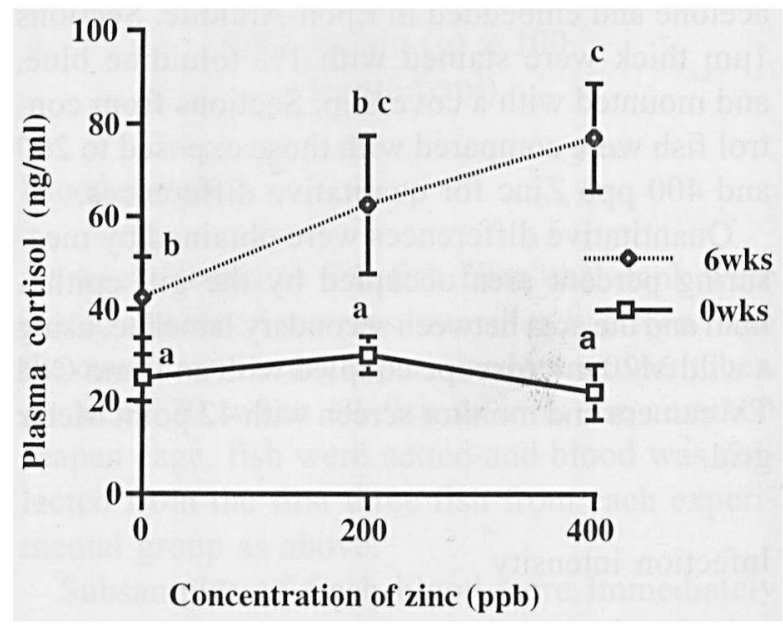

Fig. 2. Average plasma cortisol values $\pm \mathrm{SE}$ for Atlantic salmon at week 0 and after 6 weeks of treatment with either 200 or 400 ppb zinc. No significant differences exist at week 0 . At week 6 , means with the same letter are not significantly different. 

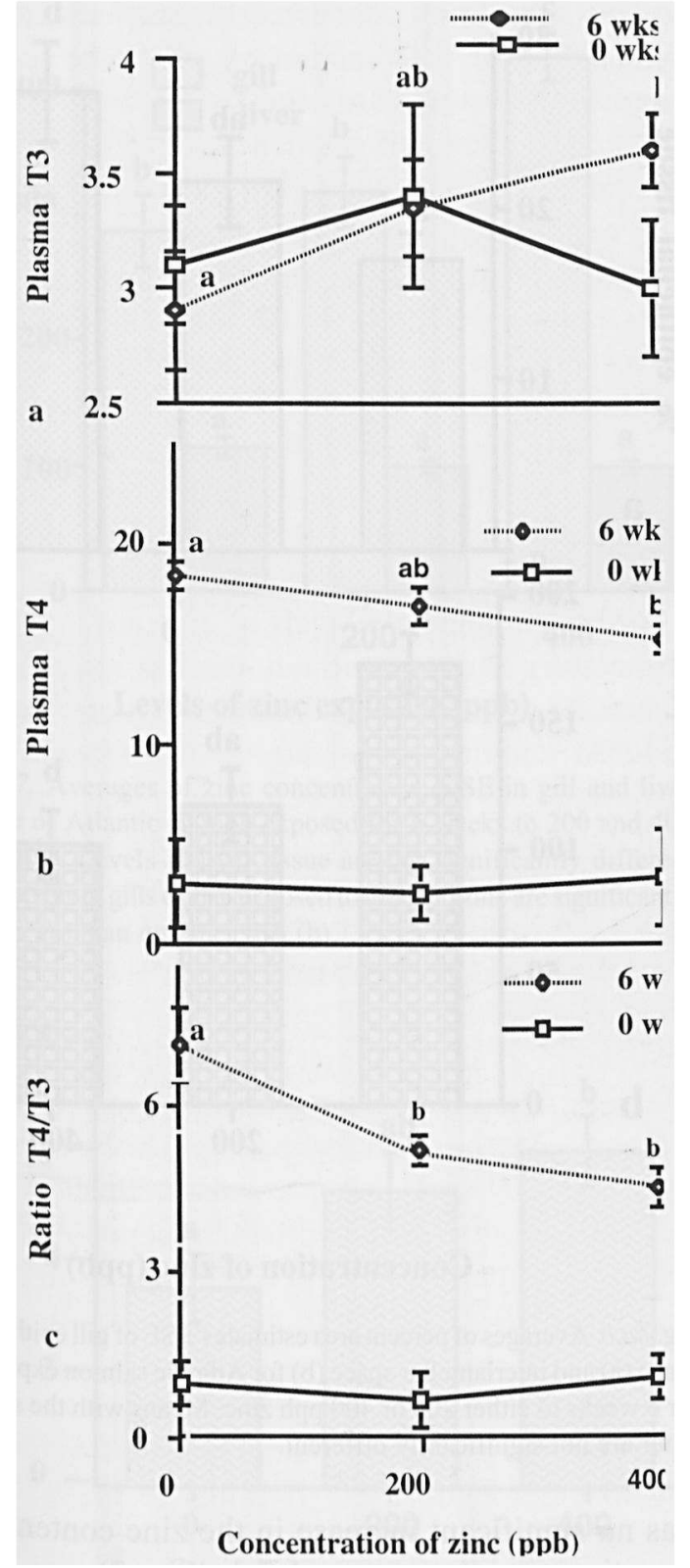

Fig. $3 a, b, c$. Average concentration $\pm \mathrm{SE}$ of plasma $\mathrm{T}_{3}$ (a) and $T_{4}(b)$ and the average ratio of $T_{4} / T_{3}(c)$ in Atlantic salmon at week 0 and after 6 weeks of treatment with either 200 or 400 ppb zinc. Levels at week 0 are not significantly different. Within each graph,means with the same letter are not significantly different.

compared with controls at week 0 and 6 . Although levels of plasma glucose were all significantly lower at week 20 , levels in fish previously exposed to 200 or 400 ppb zinc were significantly higher than in control fish (Fig. 4).

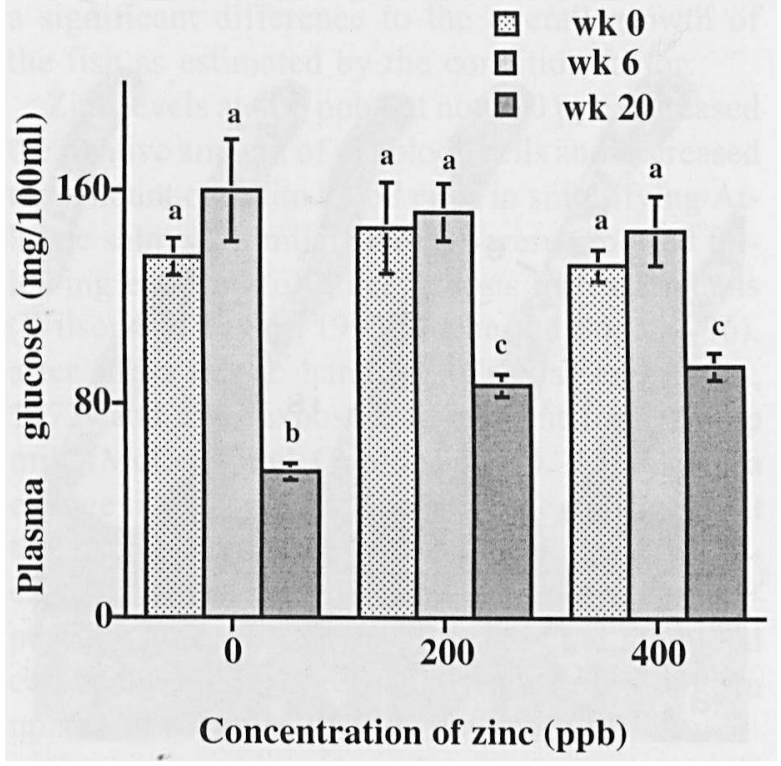

Fig. 4. Average plasma glucose concentrations $\pm \mathrm{SE}$ in Atlantic salmon at week 0 , after 6 weeks of treatment in freshwater with either 200 or $400 \mathrm{ppb}$ zinc and after a further 14 weeks without treatment in a seapen. No significant differences exist at weeks 0 or 6 (a). Levels at week 20 are significantly lower than in earlier weeks with levels in fish previously exposed to 200 or $400 \mathrm{ppb}$ zinc (c) being significantly higher than in fish not exposed to zinc (b).

\section{Histology}

Gills

Salmon given no zinc treatment had normal gill structure (Fig. 5a). Fish exposed to both 200 and $400 \mathrm{ppb}$ zinc showed evidence of pathology which included swelling of epithelial cells in the secondary lamellae, epithelial uplifting which left the pillar cells nude, clubbing at the tips of the secondary lamellae and deflection of the secondary lamellae towards the primary lamella (Figs. 5, 6).

Numerical area analysis indicated that epithelial cells swelled and water space between lamellae was reduced with increasing zinc exposure (Fig. $6 a, b)$.

Interrenal cell nuclear diameter

The means of interrenal cell nuclear diameters ranged from $5.8 \pm 0.45 \mu \mathrm{m}$ to $6.7 \pm 0.14 \mu \mathrm{m}$ and 

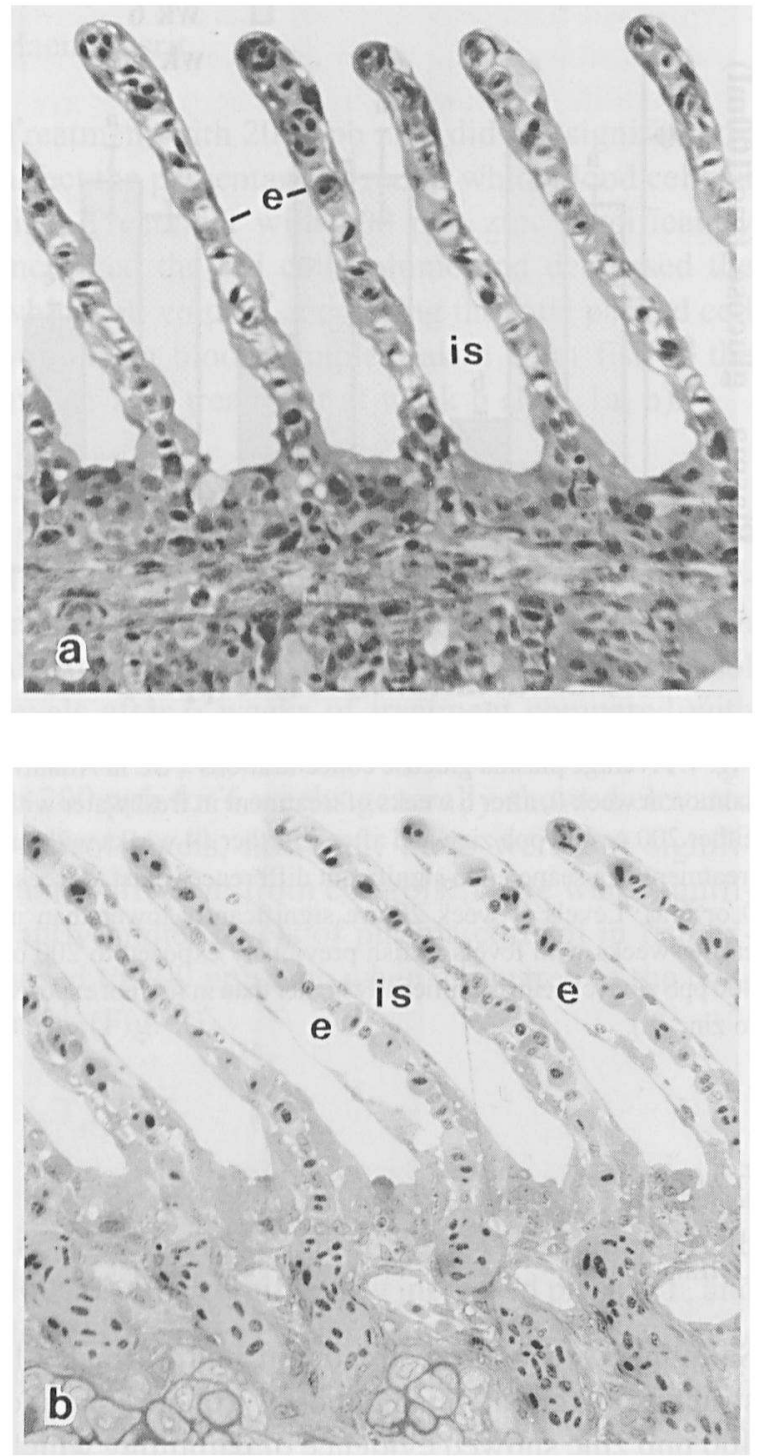

Fig. 5a,b. Light micrographs of sections of gill tissue from control Atlantic salmon (a) and from salmon exposed to $400 \mathrm{ppb}$ zinc (b). Note uplifting and swelling of epithelial layer (e) in the $400 \mathrm{ppb}$ fish. $\mathrm{e}=$ epithelium, is $=$ intralamellar space. $\times 280$

were not significantly different among treatment groups at week 0,6 or 20 .

\section{Zinc accumulation}

Zinc content in gill tissue of fish exposed to both 200 and 400 ppb zinc was significantly higher than the zinc content in gills from control fish. There

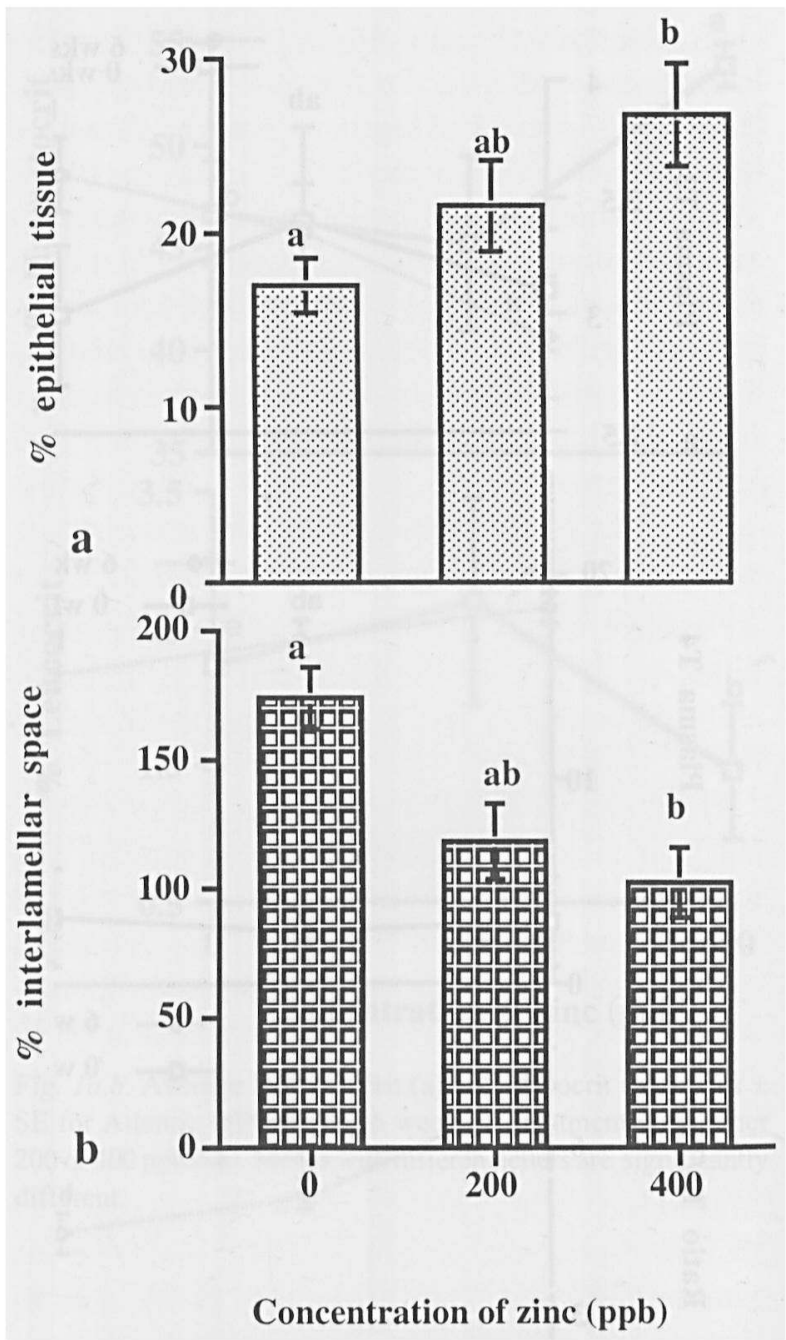

Fig. $6 a, b$. Averages of percent area estimates $\pm \mathrm{SE}$ of gill epithelial space (a) and interlamellar space (b) for Atlantic salmon exposed for 6 weeks to either 200 or $400 \mathrm{ppb}$ zinc. Means with the same letter are not significantly different.

was no significant increase in the zinc content of liver tissue in zinc-exposed fish (Fig. 7).

\section{Infection intensity}

Salmon previously exposed to or $400 \mathrm{ppb}$ zinc were infected with significantly more larvae of $L$. salmonis than were controls (Fig. 8).

\section{Discussion}

Lloyd and Herbert (1962) and Sprague (1964) have shown that $700 \mathrm{ppb}$ and $600 \mathrm{ppb}$ zinc, respectively, 


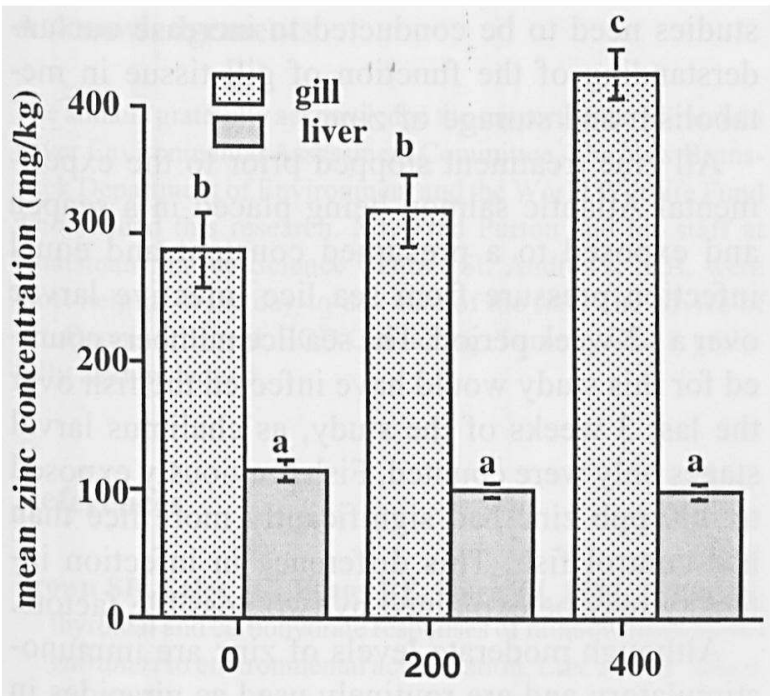

Levels of zinc exposure (ppb)

Fig. 7. Averages of zinc concentration $\pm \mathrm{SE}$ in gill and liver tissue of Atlantic salmon exposed for 6 weeks to 200 and 400 ppb zinc. Levels in liver tissue are not significantly different (a). Levels in gills of fish exposed to $400 \mathrm{ppb}$ zinc are significantly higher (c) than on other fish (b).

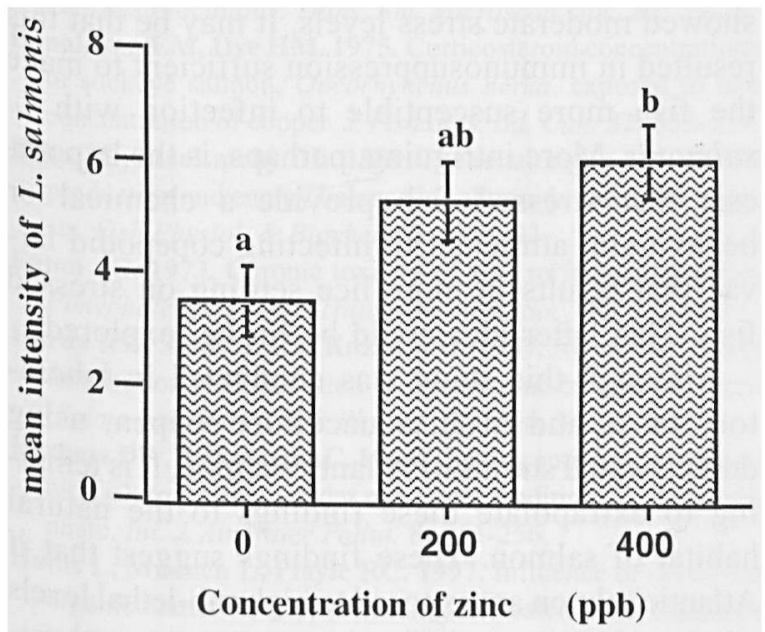

Fig. 8. Mean intensity of infection $\pm \mathrm{SE}$ 'with chalimus larvae of $L$. salmonis on Atlantic salmon exposed for 6 weeks to 200 and $400 \mathrm{ppb}$ zinc prior to 12 weeks with no zinc treatment in a seapen. Fish treated with $400 \mathrm{ppb}$ zinc (b) had significantly more lice than the control fish (a).

are lethal to Atlantic salmon under similar conditions to those used in this study. Most parameters measured in the present study indicate that zinc levels of $200 \mathrm{ppb}$ and $400 \mathrm{ppb}$ negatively affect smoltifying salmon but are not sufficient to make a significant difference to the overall growth of the fish as estimated by the condition factor.

Zinc levels at $400 \mathrm{ppb}$ but not $200 \mathrm{ppb}$ increased the relative amount of red blood cells and decreased the amount of white blood cells in smoltifying Atlantic salmon. Similar findings were reported following exposure of other teleosts to toxic metals (Wilson and Taylor, 1993; Roche and Boge, 1996), after stress due to handling (Casillas and Smith, 1977) and after exposure to effluent from a pulp mill (McLeay and Gordon, 1977). Thus such a change in relative blood cell volume indicates that the fish showed general signs of stress. Specifically, the increase in red blood cells in fish exposed to $400 \mathrm{ppb}$ zinc may be a result of red blood cell proliferation in response to impaired oxygen uptake in the gills.

Supporting these observations are the elevated plasma cortisol levels in fish receiving zinc treatment. Elevated plasma cortisol levels were also reported by Donaldson and Dye (1975) and by Schreck and Lorz (1978) in sockeye salmon after exposure to copper. Cortisol levels are an appropriate measure of acute stress while plasma glucose levels reflect more chronic stress levels. Plasma glucose levels rise in fish exposed to various pollutants (McLeay and Gordon, 1977; Wedmeyer, 1972). Surprisingly, when measured immediately after 6 weeks of treatment, plasma glucose levels were not greater in fish receiving zinc treatments than in control fish. Glucose levels dropped once fish were in the seapen, presumably as a result of less crowding than when kept in tanks. Once levels were lower, a difference in glucose levels became apparent with those fish previously exposed to zinc showing higher levels, indicative of higher stress. Interrenal cell nuclear diameters were unchanged by zinc treatment in the present study. Chronic stress in fish often results in an increase in interrenal cell nuclear diameter (Mustafa, 1997; Yang and Albright, 1995) although Scott and Rennie (1980) suggested that nuclear diameter does not always accurately reflect adrenal cortical activity.

Thus, although haematocrit changes and cortisol levels suggest that salmon were stressed when exposed to $400 \mathrm{ppb}$ zinc, other physiological parameters such as interrenal cell nuclear diameter, that usually alter during chronic stress, were un- 
changed. The mixed results with respect to measurements of stress level in salmon in the present study suggest that exposure to 200 and $400 \mathrm{ppb}$ zinc only moderately affected the stress level of Atlantic salmon.

Plasma cortisol levels and $\mathrm{T}_{4}$ levels were elevated in fish after six weeks of treatment, even in control fish. These elevations may well be due to physiological changes associated with smoltification as elevated levels of these hormones have been reported before in Atlantic salmon smolts (McCormick and Björnsson, 1994).

Thyroid hormone levels are affected by both acute and chronic stress in fish. High levels of cortisol cause a decrease in $T_{4}$ to $T_{3}$ conversion (Eales and MacLatchy, 1989). Plasma $T_{3}$ levels are reduced in trout chronically exposed to low $\mathrm{pH}$ and aluminum (Brown et al., 1984). In the present study, despite the elevated cortisol levels, zinc exposure actually appeared to improve conversion of $\mathrm{T}_{4}$ to $\mathrm{T}_{3}$ and thus may have benefited thyroid metabolism as $T_{3}$ is the form of thyroid hormone most actively utilized by fish. It would appear that high levels of zinc override the usual negative relationship between $T_{3}$ and cortisol by stimulating an increase in plasma levels of both hormones. These findings further indicate that zinc exposure had only a moderate effect on stress in Atlantic salmon smolts in this study.

That zinc treatment only moderately affected stress levels in these fish is surprising as gill pathology was evident in both the $200 \mathrm{ppb}$ and 400 $\mathrm{ppb}$ treatment groups. Swelling and uplifting of epithelial cells, as seen in this study, is consistent with gill damage resulting from zinc exposure as described by Tuurala and Sovio (1982). The extent of gill damage in the present study would be expected to reduce oxygen uptake (Skidmore and Tovell, 1972), in fish exposed to $400 \mathrm{ppb}$ zinc. Gills are the primary organ of fish affected by metal toxicity (Hollis et al., 1997). Although other species of fish, such as the brown bullhead, Ictalurus nebulosus, accumulate zinc also in the liver and kidney (Joyner, 1961), Atlantic salmon do not use the liver as a major storage organ for zinc (Hardy et al., 1987). This is supported by the present results of zinc content analysis which showed accumulation in the gills but not in the liver. Further studies need to be conducted to increase our understanding of the function of gill tissue in metabolism and storage of zinc.

All zinc treatment stopped prior to the experimental Atlantic salmon being placed in a seapen and exposed to a presumed constant and equal infection pressure from sea lice infective larvae over a 12-week period. The sea lice numbers counted for this study would have infected the fish over the last 3 weeks of the study, as chalimus larval stages only were counted. Fish previously exposed to $400 \mathrm{ppb}$ zinc had significantly more lice than had control fish. This difference in infection intensity may be explained by two possible factors.

Although moderate levels of zinc are immunostimulatory and are routinely used as viracides in mammals, zinc treatment has been associated with reduced immunocompetancy in fish (Sarato and Perlmutter, 1976). It is well known that stressed fish are more susceptible to infections as a result, in part, of reduced immuno- competence (Maule et al., 1989; Mazeaud and Mazeaud, 1981). Atlantic salmon smolts exposed to zinc in this study showed moderate stress levels. It may be that this resulted in immunosuppression sufficient to make the fish more susceptible to infection with $L$. salmonis. More intriguing, perhaps, is the hypothesis that stressed fish provide a chemical or behavioural attractant to infecting copepodid larvae that results in more lice settling on stressed fish. This latter idea could be further explored.

Although this study was conducted in laboratory tanks and in an aquaculture seapen, using domesticated strains of Atlantic salmon, it is tempting to extrapolate these findings to the natural habitat of salmon. These findings suggest that if Atlantic salmon are exposed to high sub-lethal levels of zinc during smoltification, subsequent physiological changes may predispose these fish to increased infections from organisms such as sea lice that they are exposed to once they migrate to sea. This study suggests that pathological effects of exposure of Atlantic salmon smolts to $\mathrm{ZnSO}_{4}$ become statistically evident between 200 and 400 $\mathrm{ppb}$, as indicated by susceptibility to infection with sea lice. Gill pathology was evident at $200 \mathrm{ppb}$ suggesting that the No Observed Pathological Effect (NOPE) level may be around $150 \mathrm{ppb}$. 


\section{Acknowledgements}

The authors gratefully acknowledge the support of the Miramichi River Environmental Assessmeit Committee, The New Brunswick Department of Environment and the World Wildlife Fund who funded this research. Mr. Fred Purton and his staff at Huntsman Marine Science Centre, St. Andrews, N.B. were most helpful in the day-to-day care of the fish. The advice of Mr. Dennis O'Dowd, BOD Consulting, Toronto, ON, is gratefully acknowledged.

\section{References}

Brown SB, Eales JG, Evans RE, Hara TJ. 1984. Interrenal, thyroidal and carbohydrate responses of rainbow trout Salmo gairdneri to environmental acidification. Can. J. Fish. Aquat. Sci. 41: 36-45.

Brungs WA. 1969. Chronic toxicity of Zine to the fathead minnow, Pimephales promelas. Trans. Am. Fish. Soc. 98: 272279.

Casillas E, Smith LS. 1977. Effect of stress on blood coagulation and haematology in rainbow trout Salmo gairdneri. $J$. Fish Biol. 10: 481-491.

Crandall CA, Goodnight CJ. 1963. The effects of sublethal concentrations of several toxicants to the common guppy Lebistes reticulatus. Trans. Am. Microscop. Soc. 82: 59-73.

Donaldson EM, Dye HM. 1975. Corticosteroid concentrations in sockeye salmon, Oncorhynchus nerka, exposed to low concentration of copper. J. Fish. Res. Bd. Can. 32: 533-539.

Eales JG, MacLatehy DL. 1989. The relationship between T3 production and energy balance in salmonids and other teleosts. Fish Physiol. \& Biochem. 7: 289-293.

Eaton JG. 1973. Chronic toxicity of zinc to fathead minnow, Pimephales promelas. Trans, Am. Fish. Soc. 98: 272-279.

Hardy RW, Sullivan CV, Koziol AM. 1987. Absorbtion, body distribution, and excretion of dietary zinc by rainbow trout (Salmo gairdneri). Fish Physiol. Biochem.3: 133-143.

Herbert DW, Wakeford AC. 1964. The susceptibility of salmonid fish to poisons, under estuarine conditions. I. Zinc sulphate. Int. J. Air Water Pollut. 8: 251-256.

Hollis L, Muench L, Playle RC. 1997. Influence of dissolved organic matter on copper binding and calcium on cadmium binding, by gills of rainbow trout. J. Fish. Biol. 50: 703-720.

Joyner T. 1961. Exchange of zinc with environmental solutions by brown bullhead. Trans. Amer. Fish. Soc. 90: 444-448.

Karnovsky MJ. 1965. Formaldehyde-gluteraldehyde fixative of high osmolarity for use in electron microscopy. $J$. Cell Biol. 27: 137A-138A.

Lloyd R. 1960. The toxicity of zine sulphate to rainbow trout. Ann. App. Biol. 48: 84-94.

Lloyd R, Herbert WM. 1962. The effect of the environment on the toxicity of poison to fish. J. Inst. Public Health Eng. July: 132-145.

Margolis L, Esch GW, Holmes JC, Kuns AM, Schad GA. 1982. The use of ecological terms in parasitology (Report of an ad hoc Committee of the American Society of Parasitol- ogy). J. Parasitology 68: 131-133.

Maule AG, Tripp RA, Kaattari SL, Schreek CB. 1989. Stress alters immune function and disease resistance in Chinook salmon Oncorhynchus tshawytscha. J. Endocrinology 120: 135-142.

Mazeaud MM, Mazeaud F. 1981. Adrenergic response to stress in fish. In: Pickering AD ed. Stress and Fish. New York: Academic Press, 49-75.

MeCormick SD, Björnsson BTh. 1994. Physiological and hormonal differences among Atlantic salmon parr and smolts reared in the wild, and hatchery smolts. Aquaculture 121: 235-244.

McLeay DJ, Gordon MR. 1977. Leucocrit: A simple hematological technique for measuring acute stress in salmonid fish including stressfull concentrations of pulpmill effluent. $J$. Fish. Res. Bd . Can. 34: 2164-2175.

Mustafa A. 1997. Host factors important in determining infection intensity with the sea louse, Caligus elongatus Nordmann, in Atlantic salmon Salmo salar L. and Arctic charr, Salvelinus alpinus. Ph.D. Thesis. University of New Brunswick.

Roche H, Bogé G. 1996. Fish blood parameters as a potential tool for idéntification of stress caused by environmental factors and chemical intöxication. Marine Env. Res. 41(1): 2743.

Sandell EB. 1968. Colorimetric determination of traces of metals. New York: Interscience Publishers Inc, 941-954.

Sarato DA, Perlmutter A. 1976. The toxicity of zine to immune response of the zebrafish, Brachydanio rio, injected with viral and bacterial antigen. Trans. Am. Fish. Soc. 105: 456-549.

Schreck CB. 1982. Stress and rearing of salmonids. Aquaculture 28: 241-249.

Schreck CB, Lorz HH. 1978. Stress response of Coho salmon, Oncorhynchus kisutch elicited by cadmium and copper and potentiál use of cortisol as an indicator of stress. $J$, Fish. Res. Bd. Can. 35: 1124-1129.

Scott DBC, Rennie SE. 1980. Nuclear diameter as a criterion of adrenocortical activity in a teleost fish Coregonus lavaretus (L.). J. Fish Biol. 17: 83-90.

Skidmore JF. 1970. Respiration and osmoregulation in rainbow trout with gills damaged by zinc sulphate. $J$. Exp. Biol.. 52: 481-494.

Skidmore JF, Tovell PWA. 1972. Toxic effects of zinc sulphate on the gills of rainbow trout. Water. Res. 6: 217-230.

Snieszko SF. 1960. Microhaematocrit as a tool in fishery research and management. U.S. Fish and Wildl. Serv. Spec. Rep. Sci. Rep. 341: 1-5.

Sokal RR, Rohlf FJ. 1969. Biometry. San Francisco: W.H. Freeman and Company, :

Spehar RL. 1976. Cadmium and zinc toxîcity to flagfish, Jordanella floridea. J. Fish. Res. Bd. Can. 33: 1939-1945.

Sprague JB. 1964. Lethal concentrations of copper and zine for young Atlantic salmon. $J_{x}$ Fish. Res. Bd. Can. 21(1): 1726

Sprague JB, Elson PF, Saunders RL. 1964. Sublethal copperzine pollution in salmon river, a field and laboratory study. Adv. Water Poll. Res. Bd. Can. 33: 139-45. 
Spry DJ, Wood CM. 1985. Ion flux rates, acid-base status, and blood gases in rainbow trout, Salmo gairdneri exposed to toxic zine in natural soft water. Can.J. Fish. Aquat. Sci. 42: 1332-1341.

Tuurala H, Sovio A. 1982. Structural and circulator changes in secondary lamellae of Salmo gairdneri gills after sublethal exposures to dehydroabietic acid and zinc. Aquat. Toxicol. 12: 21-29.

Wedmeyer G. 1972. Some physiological consequences of handling stress in juvenile coho salmon (Oncorhychus kisutch) and steelhead trout (Salmo gairdneri). J. Fish Res, Bd. Can. 29: 1780-1783.

Wilson RW, Taylor EW. 1993. The physiological responses of fresh water rainbow trout Oncorhynchus mykiss, during acutely lethal copper exposure. $J$. Comp. Physiol. 8: 163: 38-47.

Yang CZ,Albright LJ. 1995. Elevation of plasma cortísol and hypertrophic response of interrenal and chromoffin tissues of rainbow trout, Oncorhynchus mykiss (Walbaum) to harmful diatom Chaetoceros concavicornis. $J$. Fish Dis. 18: 165174.

Zar JH. 1984. Biostatistical analysis. N.J.: Prentìce Hall Englewood Cliffs, 1-620.

Received: 4 January 1999 